\title{
Relationship between the Management Characteristics and Earnings Management in Chinese Listed Companies
}

\author{
Lingyun Wang, Gumende Rumbidzai Florence, Enhua Hu, and Yue Sun
}

\begin{abstract}
Since earnings management is financial behavior under the control of managers, what kind of management is more likely to engage in earnings management? Firstly, this paper theoretically analyzes the mechanism of management characteristics on the impact of earnings management. Secondly, this paper does empirical study taking 216 listing corporations which have implemented equity incentive as the research sample. Then, we establish the regression model and analyze the effects of age, education level, power and equity incentive level of management on earnings management. The result shows that there is no evidence of an association between the age of management and earnings management. The effect of the constitution dimension of management rights on earnings management isn't consistent which leads to weak correlation between the management power and earnings management. The education level and equity incentive level of management is positively corrected with earnings management.
\end{abstract}

Index Terms-Management characteristics, equity incentive, earnings management.

\section{INTRODUCTION}

Equity incentive is an important way to motivate employees of listing corporation. The price of stock grants, option exercise price and exercise conditions have a major influence on equity incentive earnings. The equity incentive object will easily obtain high equity gap with lower equity price, higher exercise price and lower exercise conditions so as to promote them reduce the equity price and improve the option exercise price for their own interests. According to the China securities management regulations, the equity price of the listed companies is mainly decided by the share price of the secondary market. The price is the higher one between the previous day closing price of the equity incentive plan and the average price of the previous twenty trading days. Performance is an important determinant of stock prices. In order to improve the equity incentive rewards, management can achieve ultimate performance through the selection and adjustment of accounting methods, accounting estimates and the occurrence of accounting behavior point that is earnings management in the range of allowable accounting standards. Such behavior of listed companies has become common. At the end of 2001, the manager use illegal means to inflate revenues and profits

Manuscript received May 17, 2016; revised August 1, 2016. This work was supported with foundations: Project (NR2014011, NS2015082) funds for the Central Universities; Project $(71473131,71573123)$ the National Natural Science Foundation of China; Project (16BGL106 ) National social science fund of China.

The authors are with the College of Economics and Management, Nanjing University of Aeronautics and Astronautics, Nanjing, 211106, China (e-mail: helwly@163.com, rgumende@gmail.com, hrmnuaa@163.com,815608234@qq.com). and deliberately raise the stock price for their own profit in Enron's accounting fraud events. Erie shares and Hainan pharmaceutical's deficit in 2007 was because of the provision of equity incentive fee. After the Gold Mantis Company launch equity incentive plan in 2008, the company's non recurring gains and losses fell suddenly which drove down the stock price. So what kind of manager has the tendency of earnings management? Can one prevent the earnings management through understanding of the management features? At present, this kind of research is rare. So this article attempts to carry on related studies.

\section{ANALYSIS OF THE IMPACT OF MANAGER CHARACTERISTICS ON EARNINGS MANAGEMENT}

In Upper Echelons Theory, Manager's Characteristics affect their decisions, which affect company's action. Management characteristics refer to his age, term, professional background, education, gender, race, social economic base financial conditions and power, etc., because these characteristics determine the preference in management (Hambrick\&Mason, 1984 [1]; Xiang Kaibiao\&Xian Heng, 2013 [2]). In addition, the agency theory thinks that executives' preferences and personality would also affect executive decisions(Victor \& Miguel, 2014 [3]) .This paper mainly analyzes the impact of the age, education level, power and the equity incentive level of management on earnings management.

\section{A. How Does Management's Age Affect Earnings Management}

According to the theory of career, with the increase of the age of management, they have lower desire for money and pay more attention to the long-term development of enterprises. Then, their motivation of excess profits through earnings management will become smaller.

Hypothesis 1: Management age has a negative effect on Earnings Management.

\section{B. How Does Management's Education Level Affect Earnings Management}

The exercise price and market price of equity incentive have an important effect on equity incentive income. This needs to be taken into account when management designs the equity incentive system. The higher the education level of management is, their understanding of equity incentive plan will be more thoroughly and they will more likely design their favorable scheme.

Hypothesis2: Management's education level is positive relative to earnings management.

\section{How Does Management's Power Affect Earnings Management}

The shareholders give the management resource 
allocation right, decision right, et al., in order to make the management run the company more convenient. Earnings management is an invisible power of management and it reflects the subjective intention of managers. But the implementation often resorts to financial personnel's behavior. When the management's power is large, their influence in company will also be large. The financial person will be more likely to follow their instructions. All these make it helpful to them to conduct earnings management.

Hypothesis3: Management's power is positive relative to earnings management.

\section{How Does Management's Equity Incentive Level Affect Earnings Management}

Cheng and Warfield (2005) [4] find that management with high equity incentive are more likely to sell shares in the future, which prompts managers to engage in earnings management to increase the sale of stock price. Bergstresser and Philippon (2006) [5] find a significant positive correlation between the equity compensation as a proportion of CEO's return and the earnings management represented by discretionary accruals. Xi Zhao, Yanli Shi and Yong zhang (2008) [6] found that, the Chinese management's equity incentive compensation as a proportion of total compensation is positive relative to earnings management level. When Kanagaretnam (2012) [7] research the relationship between CEO's stock option and the accuracy and bias of analysts' earnings forecasts, he found that a higher level of stock options may cause CEO's to conduct high risk projects, change or redistribution their wok and may be involved in the opportunity return and information disclosure management.

Hypothesis4: Management's equity incentive level is positive relative to earnings management.

\section{The EMPIRICAL STUdy Design}

\section{A. Sample Selection}

The samples are listed corporations of China. These corporations implemented equity incentive plan in Shanghai and Shenzhen before December 31, 2012. The motivations of earnings management in Chinese listing companies are multiaspect, while the focus of this paper is earnings management to maximize returns. To avoid the effect of earnings management of nonpayment on this research and improve the accuracy of earnings management's measurement and the validity of results, samples in this research mainly come from Chinese financial CCER database (www.ccerdata.cn), the annual report released by the website of Shenzhen stock exchange, Shanghai stock exchange and equity incentive announcement released by the huge influx of information network (www.cninfo.com.cn). Besides, it also refer to announcement of the shareholders' general meeting and board of directors and China announcement Securities Journal and other financial newspaper. The result is that there is 280 companies that have implemented equity incentive till the end of 2012. In order to keep the effectiveness of the sample, we will screen these samples according to the following principles to control the interference of the earnings management because of nonpayment. (1) Removing the samples of controlled companies such as financial and insurance companies, because the accounting statements of financial and insurance companies are quite different from other industries. Besides, its accrued profits are special and not suitable for Jones model. (2) Removing the samples of PT companies, ST companies and deficit companies. In order to cancel the financial deficit, the motivation to modify the accounting book will be very strong. Besides, there are management problems of ST, PT and deficit companies typically. This paper mainly focuses on the listing companies under normal circumstances, so ST, PT and deficit companies are removed. (3) Removing the samples of companies that listed from 2012, because the calculation of accrued profit needs the financial data of last year. (4) Removing the samples of the list companies from which the management do not get salaries. (5) Removing the samples of companies whose financial data, corporation governance data and salaries data are missing. At last, we choose 216 companies as the entire sample from 280 listing companies.

\section{B. Variables Selection}

\section{1) The dependent variable}

The dependent variable is earnings management. The aim of earnings management's conduction is to modify the information in accounting statements, but not change the real cash flow. So, if one wants to know the extent of earnings management, they can compare the company's balance sheet and cash flow statement to find out the difference between the profit in statements and actual cash flow. According to empirical accounting standards, enterprise profit is divided into two parts. One part is the profit of already realized cash flow, namely the cash flow from operating activities. Another part is the earnings that have not achieved inflow, namely accrued profit. Because the cash flow is really happen, so the company is hard to control. As a result, it is assumed that the earnings management can only be manipulated by accrued profit. Because the accrued profit has uncertainty during certain time, the management has the chance to conduct earnings management. According to accruals method, the accrued profit is divided into discretionary profit and nondiscretionary profit. Nondiscretionary profit is usually compulsive handled according to the existing accounting standards. So, it is difficult to control. The left part is the manipulation of accruals, such as changes in accounting estimates, or the accrued profit manipulated by deferred income, capital expenditure and impairment of assets. The modified Jones model is the most effective and common method to measure the discretionary profit. The theory evidence of the model is that the nondiscretionary profit is influenced by the level of fixed assets and operating revenue except accounts receivable. Combined with formal analysis, we calculate the accrued profit and nondiscretionary profit, and then figure out the discretionary profit. Considering Chinese stock market was born in short time, it is difficult to collect data for long time. When one estimate model parameters, the time series cannot satisfy the requirement. Research has found that using cross model can solve the shortage of time and the change of corporate structure and it can identify earnings management successfully. So, one can choose the cross model.

- The calculation of total accruals

$$
T A_{i, t}=I_{i, t}-C F O_{i, t}
$$


$T A_{i, t}$ represents company i's total accruals during period t. $I_{i, t}$ represents company i's net profit during period t. $C F O_{i, t}$ represents company i's net cash flow from operating activities during period $t$.

- The estimated values of the parameter of the model

$$
\begin{aligned}
& T A_{i, t} / A_{i, t-1}=\alpha_{1}\left(1 / A_{i, t-1}\right)+\alpha_{2}\left(\Delta R E V_{i, t} / A_{i, t-1}\right)+ \\
& \alpha_{3}\left(P P E_{i, t} / A_{i, t-1}\right)+\xi_{i, t}
\end{aligned}
$$

$\triangle R E V_{i, t}$ represents company i's change of business income in year t. $P P E_{i, t}$ represents company i's fixed assets during period t. $A_{i, t-1}$ represents company i's total assets during period t-1. $\xi_{i, t}$ represents residual of regression equation. ( $\mathrm{a}$ is the estimated value regressed by the affiliated industry, ta is the total accrued profit of non sample company from the same industry )

- We get the estimated value of $a_{1}, a_{2}, a_{3}$ by above model, and then calculate the nondiscretionary profit of each listing companies. The calculation model as follows:

$$
\begin{aligned}
& N D A_{i, t}=a_{1}\left(1 / A_{i, t-1}\right)+ \\
& a_{2}\left(\Delta R E V_{i, t} / A_{i, t-1}-\Delta A R_{i, t} / A_{i, t-1}\right)+a_{3}\left(P P E_{i, t} / A_{i, t-1}\right)
\end{aligned}
$$

$N D A_{i, t}$ is nondiscretionary profit, $\triangle A R_{i, t}$ represents company i's change of accounts receivable during period $t$.

- Calculating discretionary profit $D A_{i, t}$. According to the total accruals equals discretionary profit and nondiscretionary

profit. $T A_{i, t} / A_{i, t-1}=N D A_{i, t}+D A_{i, t}$. We can figure out:

$$
D A_{i, t}=T A_{i, t} / A_{i, t-1}-N D A_{i, t}
$$

$D A_{i, t}$ is discretionary profit.

\section{b) The independent variables}

The independent variables are age, education level, power and equity incentive level of management. The age of management is measured by their actual age. The education level of management is divided into junior high school and below, high school and polytechnic school, junior college and undergraduate, master degree candidate, doctoral candidate, respectively for $1,2,3,4,5$. The power of management is measured by four dimensions, respectively for the management organization structure power, expert power, prestige power and proprietary rights power. The management organization structure power depends on whether the chairman and the general manager are occupied by one person. If so, we use 1 to mark it, or 0 . Expert power depends on whether he has key experience. If so, we use 1 to mark it, or 0 . Prestige power variable refers to the overall evaluation of the managers in the industry. There are three scales, respectively for commendatory, derogatory sense and neutral. We use 1 to assign commendatory and neutral and use 0 to assign derogatory sense. Proprietary rights power depends on whether the management is the founder or not. If so, it is marked by 1 , or 0 . The equity incentive level of management is measured by the method put forward by Bergstresser and Philippon (2006) [5]. The following formula can be used to calculate the proportion of stock option compensation in total compensation:

$$
\operatorname{INCENTIVES}_{i, t}=\frac{0.01 \times \text { PRICE }_{i, t} \times\left(\text { CSHARES }_{i, t}+\text { OPTIONS }_{i, t}\right)}{0.01 \times \text { PRICE }_{i, t} \times\left(\text { CSHARES }_{i, t}+\text { OPTIONS }_{i, t}\right)+\text { CASHPAY }_{i, t}}
$$

INCENTIVES represents the proportion of stock option compensation in total compensation. PRICE ${ }_{i, t}$ represents company i's closing price in the end of the year t. CSHARES $_{i, \mathrm{t}}$ and OPTIONS $S_{i, t}$ represents the amount of stocks and options owned by the management of company $i$ in year t. CASHPAY ${ }_{i, t}$ is the cash compensation of management, including salary and allowances.

(3) Controlled variable. Most of previous researches adopt company scale (Min Luo, 2010 [8]; Zengfu Li, Zhiqiang Dong and Yujun Lian 2011 [9]), asset-liability ratio (Xiangdong Zhong, 2011 [10]; Jianxing Geng, 2012 [11]) and Character of the Largest Shareholder (Weian Li, 2010 [12]; Fan He, 2010 [13]) as the controlled variable to improve the reliability of the research. The nature of the company uses dummy variable. If it is a state-owned enterprise, we use 1 to mark it, or 0 .

\section{Model Design}

$$
|D A|=\beta_{0}+\beta_{1} M A N A G E M E N T+\beta_{2} S I Z E+\beta_{3} D E B T+\beta_{4} N A T U R E+\varepsilon
$$

$|D A|$ is the absolute value of discretionary accruals amount. MANAGEMENT is the management characteristic variables. It represents the age, education level, power equity incentive level of the management. SIZE is the logarithm of the total assets at the end of the year. $D E B T$ is asset-liability ratio. NATURE is the company nature.

\section{THE EMPIRICAL RESULTS AND ANALYSIS}

\section{A. Descriptive Statistics}

\section{2) The industry classification of listing companies}

According to the "Listing Corporation industry classification guidance" revised by Chinas Securities Regulatory Commission in 2012, the industry distribution of the samples is shown in the following table. From the table, 
there are 143 manufacturing listing companies among the samples, accounting for $66.2 \%$ of the total number of samples. The secondly largest proportions are information transmission, software and information technology services. There are 31 companies, accounting for $14.35 \%$ of the total. Next are realty industry, the wholesale and retail industry and construction industry. The rest of the Sample Firms distribute in agriculture Forestry Animal Husbandry and fishery culture, sports and entertainment industry, power supply industry etc. The reason of the distribution is that the manufacturing companies account for a large proportion in the listing companies. The transmission of information, software and information technology services industry belongs to the high tech industry. The industry may be influenced by the rapid development of equity incentive in the high tech industry in the foreign countries. So, there are many companies choosing equity incentive as compensation method.

(2) Descriptive statistics of variables

TABLE I: DESCRIPTIVE STATISTICS OF VARIABLES

\begin{tabular}{cccccc}
\hline & $\begin{array}{c}\text { Number of } \\
\text { samples }\end{array}$ & minimum & maximum & average value & Standard deviation \\
\hline DA $\mid$ & 216 & 0.000915 & 0.300256 & 0.059001 & 0.053458 \\
AGE & 216 & 38 & 69 & 53.36 & 7.363 \\
EDUCATION & 216 & 1 & 5 & 3.627 & 0.929 \\
POWER & 216 & 1 & 4 & 2.72 & 0.894 \\
INCENTIVES & 216 & 0.0049 & 0.998 & 0.514 & 0.369 \\
SIZE & 216 & 19.886 & 26.6608 & 21.827 & 1.254 \\
DEBT & 216 & 0.03 & 0.822 & 0.366 & 0.206 \\
NATURE & 216 & 0 & 1 & 0.13 & 0.337 \\
\hline
\end{tabular}

TABLE II: SINGLE SAMPLE T TEST OF |DA|

\begin{tabular}{cccc}
\hline & $\mathrm{t}$ & $\mathrm{df}$ & $\mathrm{Sig}$ \\
\hline$|\mathrm{DA}|$ & 16.221 & 215 & 0.000 \\
\hline
\end{tabular}

Through descriptive statistics on the variables of 216 Sample Firms, we can find that the $|\mathrm{DA}|$ mean value is 0.059001 . During the study period, the maximum value is 0.300256 and the minimum value is 0.000915 . The result shows that earnings management is common in the samples and its level is quite different among these companies. Single sample $\mathrm{t}$ test shows that there is a significant difference in $|\mathrm{DA}|$ of Sample Firms. This shows that the sample companies have abnormal Discretionary accruals, which means that there is earnings management in the equity incentive listing companies.

In addition, from the table 1 , it can be noted that the average of management is 53.36. This proves that the Chinese management is mature. The education level of management is 3.627. This shows that most managers' education level is high and more than bachelor's degree. The power level of the management is 2.72 . This shows that the Sample Firms' management authority is in the middle level and few managers 'power are in the optimal condition in all aspects. The average proportion of the managers' stock option compensation account for total compensation is $51.4 \%$, the maximum is $99.8 \%$, the minimum is $0.49 \%$ and the standard deviation is $36.9 \%$ which shows that equity incentive level has large difference between different Sample Firms. Compared with the management equity incentive level in foreign listing Corporation, the amount of Chinese listing companies implementing equity incentive is fewer, accounting for about $10 \%$ of the total number of listed company in Chinese A stock market and the level is lower, less than $30 \%$.

In the aspect of controlled variables, the maximum and the minimum of the company scale is not large which shows that the difference of the samples' assets scale is small and well-distributed. The average of asset-liability ratio is $36.6 \%$ which proves the sample firms tend to have robust capital structure. Company nature variable mean value is 0.13 . It shows that most of the sample firms are non state-owned enterprises. Only 28 are state-owned enterprises, mostly private enterprises. Because China private enterprises have more freedom of operation, the ownership arrangement is more free and flexible.

\section{B. Empirical Analysis}

Discretionary accruals can be put as the dependent variable. The first step is to put control variables into the regression equation. The second step is to put the age, education level, power and equity incentive level of management into the regression equation. From the multicollinearity analysis, it can be noted find that the expansion factor is between 1.206 and 2.267 and less than 10 , which shows that there are no multicollinearity problems between the variables. The result is shown in table 3 . It is seen from table 3 , after the age joining the regression equation, the $\mathrm{R}^{2}$ does not change significantly, which shows that the manager's age has little effect on Earnings Management. After the education level joining the regression equation, the $\mathrm{R}^{2}$ changes a lot. But the level of significance is low, only significant at the 0.1 level. After the power joining the regression equation, the $\mathrm{R}^{2}$ does not change a lot and the level of significance is not obvious. After the equity incentive variables of management joining the regression equation, the $\mathrm{R}^{2}$ changes a lot and the level of significance is obvious. Thus hypothesis 1and 3 have not been validated and hypothesis 2 and 4 has been verified.

As a statistical matter, managers' age is not significantly associated with earnings management. The result is not against the existing research. Few studies have proved related. The education level of the management is corrected with earnings management. It is mainly because earnings management needs strong professional foundation and good education experience to help managers manipulate earnings management better. Correlation between earnings management and power of management is not significant and is not completely consistent with the existing research. 
The power of management is divided into four dimensions, respectively for the management organization structure power, expert power, prestige power and proprietary rights power. From a logical point of view, organization structure and expert power help managers to implement earnings management. But the prestige power is obtained because of good moral character, which should lead to avoid earnings management. In this paper, proprietary rights power refers to the founder. The founder should pay attention to the long-term development of enterprises. So, he has no motivation to conduct earnings management. But due to the particularity of Chinese stock market, it cannot be avoided that there is a few people implement earnings management for cash. Above all, each power source of managers has different effect on the direction of earnings management, which leads to its relationship with earnings management is not obvious. The result that the equity incentive is positive correlated with earnings management is consistent with the results of the current mainstream.

TABLE III: STEPWISE REGRESSION ANALYSIS RESULTS

\begin{tabular}{|c|c|c|c|c|}
\hline $\begin{array}{l}\text { independent } \\
\text { variable }\end{array}$ & dependent variable & $|\mathrm{DA}|$ & Value P & $\Delta \mathrm{R}^{2}$ \\
\hline & Model 1 & Model 2 & & \\
\hline SIZE & 0.003 & 0.003 & & \\
\hline DEBT & $0.061^{* *}$ & $0.069^{* *}$ & & \\
\hline NATURE & -0.016 & -0.010 & & \\
\hline AGE & & & 0.567 & 0.001 \\
\hline EDUCATION & & & 0.059 & 0.185 \\
\hline POWER & & & 0.135 & 0.064 \\
\hline INCENTIVES & & & $0.018^{*}$ & 0.212 \\
\hline
\end{tabular}

\section{RelEVAnt SugGestions}

Earnings management usually means financial behavior under the authority of management. It provides investors with wrong information and also provides unreal basis for the payroll. From this paper, education level, power and the level of equity incentives of management are likely to have a positive impact on equity incentive. In order to reduce the earnings management behavior of enterprise, we should:

\section{A. To Improve the Information Disclosure and the Punishment and Execution of Illegal Behavior}

When the managers' education level is high and power is strong, the tendency of earnings management will be heavier. An important reason is the information asymmetry among managers, large shareholders, investors, government and other institutions. Improving the information disclosure makes the information more and more transparent. So the risk of earnings management will be higher and the tendency will be smaller. Besides, to enhance the implementation of punishment is also very important measures. The manager did dare to conduct earnings management because one of the reasons is that the punishment of accounting fraud and Information manipulation is not strict no matter the accounting law or the rules of CSRC. So, managers have fluky psychology, and then violate the rules. Clear definition of irregularities and clear standards of punishment will help to monitor and inhibit managers' short-sighted and self-interest behavior.

\section{B. Using Managers of High Reputation}

One aspect, the managers of high reputation will reduce earnings management motivation because of his reputation. Another aspect, his high reputation will affect his team to reduce other people's earnings management motivation.

\section{Optimizing the Compensation System and Equity Incentive Management Measures of Listing Companies}

At present, the majority of listing corporations' exercise condition of equity incentive plan is too low and the validity of incentive period is short, which is convenient for the management to engage in earnings management. China market supervision department designs more practical exercise standard according to the different industries and personalized examine and verify the equity incentive plan of the listing companies to prevent the management from designing the stock right incentive plan because of earnings management.

\section{REFERENCES}

[1] D. C. Hambrick and P. A. M. Upper, "Echelons: Organization as a reflection of its managers," Academy Management Review, 1984, vol. 9, no. 2, pp. 193-206.

[2] K. B. Xiang and X. Heng, "Improving mental models through learning and training-Olutions to the employment problem," Journal of System and Management Sciences, 2013, no. 1, pp. 13-25.

[3] V. M. M. Seco and M. P. Lopes, "Between compassionateness and assertiveness: A trust matrix for leaders," Journal of System and Management Sciences, 2014, no. 3, pp. 622-644.

[4] Q. Cheng and T. D Warfield, "Equity incentives and earnings management," The Accounting Review, 2005, vol. 80, no. 2, pp. 441-476.

[5] D. Bergstresser and T. Philippon, "CEO incentives and earnings management," Journal of Financial Economics, 2006, vol. 80, no. 3, pp. 511-529.

[6] X. Zhao, Y. L. Shi, and Y. Zhang, "An empirical study on the earnings management reduced by managerial ownership incentive mechanism," Journal of Xidian University, 2008, no. 5, pp. 23-27.

[7] K. Kanagaretnam, G. J. Lobo, and R. Mathieu, "CEO stock options and analysts'forecast accuracy and bias," Review of Quantitative Finance and Accounting, 2012, vol. 38, no. 3, pp. 299-322.

[8] M. Luo, "Research on company characteristics, the budgetary slack and earnings management," Economic Management, 2010, no. 4, pp. 129-137.

[9] Z. F. Li, Z. Q. Dong, and Y. J. Lian, "Accrual earnings management or real earnings management activities - A study based on Chinese income tax reform in 2007," Management World, 2011, no. 1, pp. 121-134.

[10] X. D. Zhong and X. J. Fan, "Research on the relationship among the enterprises' social responsibility, financial performance and earnings management," Finance and Accounting Monthly, 2011, no. 9, pp. 14-18.

[11] J. X. Geng, C. Zhang, and F. Y. Liu, "Can venture capital improve the efficiency of the venture investment enterprises?-From the perspective of earnings management," Economic Problems, 2012, no. 9 , pp. 16-25.

[12] W. Li, "Research and evaluation of Chinese listing corporations-Data from 1127 listing corporations in 2008," Management World, 2010, no. 1 , pp. $142-151$

[13] F. He, "Research on equity incentive and earnings management-Based on empirical evidence of Chinese listing corporations," Journal of Zhongnan University of Economics and Law, 2010, no. 2, pp. 135-140. 
Lingyun Wang is an associate professor of Nanjing University of Aeronautics and Astronautics. She was born in JiAn Jiangxi China, September, 1976. She received $\mathrm{PhD}$ of business management in 2002 in Nanjing University. She has published about twenty pieces of articles in the fields of Human resource management and strategy management.

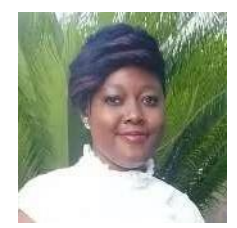

Gumende Rumbidzai Florence was born in November, 1989, in Harare of Zimbabwe. She studies in Nanjing University of Aeronautics and Astronautics, for master degree in international business since 2015 . 